\title{
Isopathic Use of Auto-Sarcode of DNA as Anti-Miasmatic Homeopathic Medicine and Modulator of Gene Expression?
}

\author{
Marcus Zulian Teixeira ${ }^{1}$ \\ ${ }^{1}$ School of Medicine, University of São Paulo, São Paulo, Brazil
}

Homeopathy 2019;108:139-148.

\begin{abstract}
Address for correspondence Marcus Zulian Teixeira, MD, PhD, Departamento de Ginecologia e Obstetrícia, Hospital das Clínicas da FMUSP, Av. Dr. Enéas de Carvalho Aguiar, 255, $10^{\circ}$ andar, sala 10.166, São Paulo, SP 05403-000, Brazil

(e-mail: mzulian@usp.br; marcus@homeozulian.med.br).
\end{abstract}

\begin{abstract}
Keywords

- homeopathy

- miasm

- epigenome

- isopathy

- auto-sarcode of DNA

Introduction In addition to the four pillars of homeopathy, vitalism and the miasmatic theory are often used to explain the health-disease process. According to Hahnemann's concepts, homeopathic miasms are the main obstacle to the cure of chronic diseases, with psora being the fundamental cause of all forms of diseases. According to modern genetics, the disease-promoting epigenetic alterations are the fundamental cause of the manifestation of chronic diseases.

Objective This article develops a philosophical-scientific correlation between chronic miasms and disease-promoting epigenetic modifications, aiming to justify the isopathic use of auto-sarcode of an individual's DNA as homeopathic medicine.

Results Based on the study of homeopathic doctrine and epigenetics, a conceptual and functional correlation is observed between homeopathic chronic miasms and diseasepromoting epigenetic modifications. Additionally, several experimental studies suggest that homeopathy's mechanism of action may be by modulating gene expression.

Conclusions By the philosophical-scientific correlations described, it is inferred that disease-promoting epigenetic alterations are the biological representation of the chronic miasms, suggesting the isopathic use of auto-sarcode of DNA as homeopathic therapeutic modulator of gene expression for the management of chronic diseases.
\end{abstract}

\section{Introduction}

The homeopathic scientific model is based on four pillars: (1) principle of therapeutic similitude; (2) homeopathic pathogenetic trials in humans; (3) prescription of individualized medicines; and (4) use of dynamized or potentized medicines (homeopathic high dilutions). Although these assumptions are enough to substantiate and apply homeopathic treatment to several health-related disorders, scientifically evidenced in hundreds of experimental and clinical studies, ${ }^{1,2}$ homeopathy also uses the philosophic concept of vitalism and the miasmatic theory to broaden the understanding of the health-disease process.

received

July 23, 2018

accepted after revision

October 25, 2018

published online

February 13, 2019
According to Samuel Hahnemann's vitalist concept, the vital force is responsible for maintaining health and preserving life, by acting on the body's physiology automatically and instinctively. Since it is strongly linked to the physical body (organic vital force or vital principle), it is said to maintain the body's sensations and functions in balance during the state of health. When 'vital dystonia' occurs, the body gets sick; in turn, healing occurs by restoring that balance. Homeopathic medicines can restore vital harmony because they are said to have a dynamic force of similar nature. By producing an artificial disease that is very similar to the natural one, it has been proposed that the homeopathic medicine acts by triggering a reaction from the vital

Copyright $\odot 2019$ The Faculty of Homeopathy
License terms

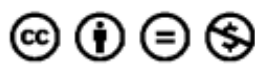

DOI https://doi.org/

10.1055/s-0038-1676810. ISSN $1475-4916$. 
principle against the pre-existing organic disturbance, removing the signs and symptoms manifested by means of the principle of symptomatic therapeutic similitude. ${ }^{3-5}$

In the miasmatic theory, which seeks to broaden the understanding about the nature of chronic diseases, ${ }^{6}$ Hahnemann adds to their etio-pathogenesis the existence of three chronic miasms of dynamic nature (psora, sycosis, and syphilis), and attributes to them the potential for being the main obstacle to the action of correctly prescribed homeopathic medicines, thus preventing the healing vital reaction from occurring. He also attributes to psora the fundamental cause of all forms of chronic diseases. To counteract the influence of these miasms and cure the resulting chronic diseases, he suggests the use of anti-miasmatic medicines.

Similarly, studies on human genome identify in the epigenetic mechanisms the fundamental cause for the manifestation of most chronic diseases. By presenting a complex and dynamic modus operandi, the epigenome regulates gene expression according to the multiple influences that an individual is subjected to throughout life. By presenting conceptual and functional similarities, the homeopathic chronic miasms find their biological representation in the disease-promoting epigenetic modifications.

In this study, I propose to describe the philosophicalscientific correlation between the miasmatic theory and epigenetics, by bringing contributions to broaden the understanding of the health-disease process described by the homeopathic model and suggesting a new therapeutic approach to chronic diseases.

\section{Aims}

The main aim of this article is to develop a philosophicalscientific correlation between chronic miasms and diseasepromoting epigenetic modifications, leading to the suggested isopathic use of auto-sarcode of DNA as anti-miasmatic homeopathic medicine and modulator of gene expression.

\section{Nature of Chronic Diseases or Homeopathic Miasmatic Theory}

In the work, The Chronic Diseases, their Peculiar Nature and their Homeopathic Cure, ${ }^{6}$ and in the chapter, 'Nature of chronic diseases', published in 1828 after decades of trials with the classic homeopathic method (individualized medicine according to the characteristic symptomatic totality), Hahnemann describes the failures that he himself observed with this therapeutic approach in cases of 'too inveterate' chronic diseases: 'The chronic disease could, despite all efforts, be but little delayed in its progress by the homeopathic physician and grew worse from year to year' (p. 3).

To explain this finding, Hahnemann infers three chronic and dynamic miasms (psora, sycosis, and syphilis) in the etiopathogenesis of these 'more deep-seated' diseases, and classifies them as 'chronic miasmatic sickness'. By expanding miasmatic etio-pathogenesis to 'all chronic diseases of mankind', he states that 'they must therefore all have for their origin and foundation constant chronic miasms, whereby their parasitical existence in the human organism is enabled to continually rise and grow' (pp. 5-9). ${ }^{6}$

By imputing to these miasms the main obstacle to curing chronic diseases in general, he attributes special importance to psora ('original malady or fundamental disease that caused so many chronic maladies' or 'the Itch disease'), which he regarded as 'the oldest and most hydra-headed of all the chronic miasmatic diseases' and from which, as their only source, originate 'at least seven-eighths of all the chronic maladies' (pp. 7-13). ${ }^{6}$

By attributing to psora a dynamic and 'fluidly infectious' nature, Hahnemann explains that it is transmitted by 'scratch continuously because of their unbearable itching, and thus the fluid was diffused around, and the psoric miasm was communicated more certainly and more easily to many other persons, the more it was concealed' (p. 11). ${ }^{6}$

In the chapter 'Cure of the chronic diseases', sub-chapter 'Psora', ${ }^{6}$ Hahnemann describes a series of external and internal environmental factors ('events in human life') that weaken the vital force and 'can bring the psora latent and slumbering to break out into open chronic diseases', such as lifestyle, diet, lack of physical activity or excesses of mental or sexual activity, trauma, acute infectious diseases, use of drugs and alcohol, smoking, inadequate treatments, and emotional and psychic disorders. He restates the importance of the mind and psyche in the etio-pathogenesis of chronic diseases, and emphasizes: 'By far the most frequent excitement of the slumbering psora into chronic diseases, and the most frequent aggravation of chronic ailments already existing, are caused by grief and vexation' (pp. 107-114).

In the same chapter, he indicates the use of specific homeopathic medicines (anti-miasmatics) to cure the miasms and their resulting chronic diseases, choosing the remedies on the basis of symptomatic similitude. To cure the sycosis miasm and gonorrhoea, he indicates the use of Thuja and Nitric acidum, while to cure the syphilis miasm and the respective disease syphilis, he indicates the use of Mercurius. In the treatment of the psora miasm and the resulting numerous symptoms and chronic diseases, Hahnemann indicates various anti-psoric medicines (Sulfur, Hepar sulfur, Sepia, Phosphorus, Lycopodium, Calcarea carbonica, Silicea, Baryta carbonica, Carbo vegetabilis, Carbo animalis, Graphites, Aurum, Platina, among others) (Subchapter 'The medicines'). ${ }^{6}$

At the end of this sub-chapter, Hahnemann discusses a possible use of the Psorinum ('potentized miasma of itch' or 'potentized itch substance', '(auto-) isopathic medicine' prepared with secretion of human scabies) as anti-psoric homeopathic medicine, although its pure effect 'has not been proved enough, by far, that a safe homeopathic use might be made of it'. He suggests this application in accordance with the philosophical correlation between the psoric miasm and 'the Itch disease', in which the 'crude original itch substance' is the biological representation of psora. Therefore, the 'potentized itch substance' would be the simillimum of psoric miasm ('The medicines', p. 155). ${ }^{6}$

By way of clarification, Hahnemann addresses these same aspects of chronic miasms in the 'Introduction' and in paragraphs 5, 72 to 81, and 204 to 206 (among others) of 
Organon, ${ }^{3}$ and names psora as 'the only real fundamental cause and producer of all forms of disease' or 'causam morborum chronicum'

\section{Life, Vitality, DNA, and Epigenome}

Every living organism, from the simplest form to the most complex one, essentially presents biochemical information that allows it to function, develop, and multiply. Most of the time, it is the DNA that stores and replicates this information from one generation to another, and it also undergoes adaptive mutations. This allows different organisms to adjust to different environmental conditions by natural selection. DNA, genetic material, or genome consists of a set of sequences of nucleotides, molecules consisting of phosphate, deoxyribose, and a nitrogenous base (adenine, thymine, cytosine, or guanine). Each specific nucleotide sequence, which generates a protein-encoding gene, is called an exon. The set of exons, in other words the encoding part of the genome, is called the exome.

Early this century, ${ }^{7}$ the Human Genome Project highlighted that only 1 to $2 \%$ of the three billion genome nucleotide sequences are responsible for the 20,000 to 25,000 protein-encoding genes (encoding DNA or exome), while the genetic material left (98\%) consists of non-encoding DNA. They also verified that the same nucleotide sequence (genes) generates hundreds of cell types and dozens of different tissues, thus highlighting the complexity of the cellular differentiation process and the resulting regulation of the body's functions. This finding brought down the key molecular biology dogma, according to which the production of protein would be limited to a single sequence of events (nucleotide sequence $\Rightarrow$ mRNA $\Rightarrow$ protein). Thus, there is another genetic control or mechanism that regulates gene expression, today known as 'epigenetics' (from the Greek prefix, epi, 'above', 'on' or 'beyond'), established in 1942 by British embryologist and geneticist Conrad H. Waddington. ${ }^{8}$

Our body consists of close to one hundred trillion cells that come from a single egg-cell or zygote (fusion of gametes' DNA), which replicates the same genome for the other cells following the signals captured that can come from within the very cells (cytoplasm), neighboring cells (including the mother's cells), and from the environment. As long as these stimuli reach the cell nucleus, they will determine the morphology, physiology, and behavior of the future embryo and individual. Accordingly, the cells respond to several different signals and stimuli, both environmental and physical (temperature, pollutants, nutrients, hormones and medicines, among others) and behavioral (lifestyle, stress, emotions and feelings, among others).

The cell nucleus is in charge of harboring the DNA which, although being infinitely larger (if stretched, the human DNA molecule is roughly $2 \mathrm{~m}$ long, while the human cell nucleus is $\sim 5 \mu \mathrm{m}$ ), is able to be stored inside it thanks to the action of nuclear proteins named histones that wrap up (roll) the DNA molecule in structures called nucleosomes. Should the DNA stay fully enveloped, the genes will not be able to decode their base sequence in the form of protein, which is necessary for the body's functions. This is precisely the moment when epigenetics comes into the picture.
So that genes can be expressed by the arrival of several signals and stimuli, the DNA molecule needs to be partially unwrapped, thus making genes accessible to the action of several transcription factors. However, different genes are expressed at different moments and, naturally, they are located in different regions in the DNA molecules (or chromosomes). Accordingly, parts of the DNA molecule are constantly unrolled and rolled back (chromosome or chromatin remodelling). This DNA remodelling takes place precisely because of epigenetic modifications: in other words, chemical changes that mostly occur in the DNA molecule and histone proteins. There are more than 100 epigenetic modifications or alterations that can affect chromatin.

In the methylation process of the DNA occurs the addition of a methyl group $\left(-\mathrm{CH}_{3}\right)$ to the cytosine nucleotide; both the methylation and acetylation $\left(-\mathrm{COCH}_{3}\right)$ processes of the lysine and arginine amino acids can occur in the histone. The modifications in the DNA and in the histones are performed by enzymes of the following types: DNA methylase/demethylase, histone methylase/demethylase, and histone acetylase/ deacetylase. The DNA methylation process, which causes the wrapping of chromatin and occurs in regions that control gene expression (called 'promoters'), is related to the silencing of genes: in other words, genes that are marked (methylated) do not encode proteins. The histone acetylation process is usually related to the unwrapping of chromatin and gene activation. ${ }^{9,10}$

Thus, the term epigenetic means genetic information additional to that which is encoded in DNA, and is used to define gene expression modifications, without modifying the genetic code of the nucleotide sequence in any way. These epigenetic modifications, or epigenome, correspond to a set of chemical processes that constitute an additional layer of gene expression regulation at transcriptional level and forge the genome functions and the phenotypic profile, by activating or deactivating genes. In theory, each tissue must present a distinct epigenome with specific epigenetic modifications that are responsible for its healthy or sick development. When it comes to general gene expression and resulting protein encoding, the genome is constituted by encoding (exome) and non-encoding (epigenome) portions, which regulate the encoding process. Strongly united, 'exome plus epigenome' synergistically act on gene expression. ${ }^{11-13}$

With the exception of constitutive chemical alterations that were genetically inherited, epigenetic modifications can be expressed in the genome of individuals at any age, as long as they come in contact with agents that promote these phenomena, by either activating or silencing the genes that are responsible for the manifestation of a wide range of diseases. ${ }^{14,15}$ Another important aspect is that these disease-promoting epigenetic modifications are reversible and, by means of epigenetic therapy, there is a search for developing techniques that are able to restore or promote their re-programming (epigenetic modulation by employing recombinant DNA technologies). Unfortunately, severe adverse events of similar therapeutic practice have prevented its widespread use. ${ }^{12,16}$

That epigenome (set of epigenetic alterations or chemical modifications that are inserted in the genome and the chromatin) can be passed on to descendant cells, maintaining 
a specific epigenetic pattern (epigenetic code or epigenotype) for generations, ${ }^{12,17}$ influencing the health-disease correlation of the descendants (epigenetic susceptibility). Thus, the phenotype becomes the outcome of not just the genotype but of the epigenotype as well, allowing added gene expression control, which shows as much plasticity as the genotype. This epigenetic code is the one that instructs the genome about when and where genes are to be expressed. ${ }^{14,15}$

As it was mentioned earlier, the expression of the epigenetic alterations on the genome is affected by distinct external and/ or internal environmental factors, such as lifestyle and habits, irradiation and pollution, hormones, medicines, inflammation, hypoxia, stress, emotional and psychic aspects. ${ }^{10,12}$ During pregnancy, for instance, harmful factors can influence the embryo's epigenetic mechanisms, and increase the risk of future development of a number of disorders and diseases such as obesity, diabetes, hypertension, depression, attention deficit hyperactivity disorder and schizophrenia. ${ }^{18}$

\section{Philosophical-Scientific Correlation among Miasms and Epigenetics}

Regarding the miasmatic theory of the homeopathic model, described in The Chronic Diseases, their Peculiar Nature and their Homeopathic Cure, ${ }^{6}$ the characteristics of the epigenetic mechanisms endorse many of Hahnemann's chronic miasmrelated observations, which were suggested in a time when there was no knowledge of genetics. If we replace the 'infectious fluid transmission' of the miasms by the 'hereditary transmission' of the genome, both phenomena present similar properties, such as most chronic diseases present a epigenetic or miasmatic (psora) cause, which prompts their onset and prevents their natural resolution. The silencing or activation of disease-promoting genes (psora latency or manifestation) occurs at any age and because of countless external and internal etio-pathogenetic factors (similar in both processes), the pathological epigenetic modifications (chronic miasms) are transmissible to future generations and can be reversed by means of epigenetic treatments (anti-miasmatic or anti-psoric medicines). These are analogies that are partly endorsed by other homeopathic researchers. ${ }^{19,20}$

Thus, under the lens of the cited aspects, I propose the hypothesis that the disease-promoting epigenetic alterations would be the biological representation of chronic miasms, described by Hahnemann as fundamental cause (psora) and the main obstacle to the cure of chronic diseases (causam morborum chronicum), by preventing the vital force from restoring the body's balance even after administering the correctly individualized homeopathic medicine.

\section{Homeopathic Medicines Act on the Genome by Modulating Gene Expression: Hypothesis and Scientific Evidence}

Based on experimental studies, since 1997, that show the effect of homeopathic medicine on repairing chromosome damage caused by toxic or radioactive stimuli, KhudaBukhsh defends the hypothesis that the mechanism of action of homeopathic medicines occurs by regulating gene expres- sion at probably one or more levels of control. ${ }^{21-23}$ After two decades researching in the area, the authors report the results of many homeogenomic and homeogenetic studies confirming the postulate that 'homeopathic remedies could deliver their benefits by interacting with the genetic blueprint', including 'epigenetic modifications such as DNA methylation'. According to this assumption, the authors state that 'homeopathic remedies would have the capacity to interact with the genome and rearrange the expression of many genes'. ${ }^{24}$

In an article that summarizes the results of in-vitro and animal studies showing how molecular biological tools can provide useful suggestions about how human organisms behave when treated with homeopathic medicine, Dei and Bernardini $^{25}$ reaffirm the hypothesis of Khuda-Bukhsh by suggesting that the action of homeopathic medicine is not quenched by ultra-high dilution and proceeds through modulation of gene expressions'. In another review, Bellavite et $\mathrm{al}^{26}$ describe experiments that show the action of homeopathic medicine on gene expression, suggesting that 'these findings support the hypothesis that homeopathic remedies could turn some important genes on or off, initiating a cascade of gene actions to correct the gene expression that has gone wrong and [that] produced the disorder or disease'.

By adding recent studies to this set of experiments, the data support the hypothesis that potentized homeopathic medicines act at gene regulatory level according to three main types of effects: change in the expression pattern of many genes, cytotoxicity or apoptosis in cancer cells, and therapeutic modification in gene expression ( - Tables $1-3$ ).

\section{Isopathic Use of Auto-Sarcode of DNA as Anti-Miasmatic Homeopathic Medicine and Modulator of Gene Expression}

After decades of failed experiments with the classical homeopathic therapeutic approach to inveterate chronic diseases, Hahnemann regarded the manifestation of chronic miasms (psora, sycosis, and syphilis) as the main obstacle to healing them and suggested the use of anti-miasmatic medicines to neutralize their influence. In turn, he locates the fundamental cause of the vast majority of chronic diseases in the psora miasm.

Based on conceptual, functional, and experimental correlations described previously, I suggest that the disease-promoting epigenetic alterations are the biological representation of chronic miasms or the fundamental cause of chronic diseases. In homeopathic terms, the pathological epigenetic modifications are the simillimum of chronic miasms.

Grounded on this hypothesis and using the reactional therapeutic method employed by the homeopathic model for over two centuries, I propose the isopathic use of potentized and individualized DNA (auto-sarcode of DNA) aiming at triggering a complex and dynamic therapeutic reaction from the epigenome (gene expression modulation).

Rather than the therapeutic similitude principle, which is applied to the set of signs and symptoms as 'the sensible and manifest representation of the disease' (Organon, paragraph $6),{ }^{3}$ the employment of the therapeutic identity principle or 
Table 1 Experiments with potentized homeopathic medicines causing change in expression pattern of many genes

\begin{tabular}{|l|l|l|l|}
\hline Author(s), date & Potentized drugs & Cell type & Effects \\
\hline $\begin{array}{l}\text { Khuda-Buksh } \\
\text { et al } 2013^{36}\end{array}$ & $\begin{array}{l}\text { Condurango 30c; } \\
\text { Hydrastis 30c }\end{array}$ & $\begin{array}{l}\text { HeLa cells } \\
\text { (HPV18 cell line) }\end{array}$ & $\begin{array}{l}\text { Distinctly different expression patterns in over } \\
100 \text { genes when compared with control }\end{array}$ \\
\hline Bigagli et al $2014^{37}$ & $\begin{array}{l}\text { Apis mellifica MT, } \\
\text { 3c, 5c, 7c }\end{array}$ & $\begin{array}{l}\text { Human RWPE-1 } \\
\text { prostate } \\
\text { epithelial cell line }\end{array}$ & $\begin{array}{l}\text { Expression of hundreds of genes show significant } \\
\text { change (MT: 391 genes up- and 495 down-regulated; } \\
\text { 3c: 558 up- and 483 down-regulated; } 5 c: 132 \text { up- } \\
\text { and 168 down-regulated; } 7 c \text { : 328 up- and } \\
\text { 352 down-regulated) }\end{array}$ \\
\hline $\begin{array}{l}\text { Marzotto et al } 2014^{38} \\
\begin{array}{l}\text { Marzo et al } 2014^{39} \\
\text { Bellavite et al } 2014^{40}\end{array}\end{array}$ & Gelsemium 2c & $\begin{array}{l}\text { Human SHSY5Y } \\
\text { neurocytes cell line }\end{array}$ & $\begin{array}{l}\text { Expression of } 56 \text { genes involved in neuronal } \\
\text { functions show significant change } \\
\text { (49 down-regulated and 7 up-regulated) }\end{array}$ \\
\hline
\end{tabular}

Abbreviation: MT, mother tincture.

Table 2 Experiments with potentized homeopathic medicines causing apoptosis in cancer cells

\begin{tabular}{|c|c|c|c|}
\hline Author(s), date & Potentized drugs & Cell type & Effects \\
\hline $\begin{array}{l}\text { Sunila et al } 2009^{42} \\
\text { Preethi et al } 2012^{43}\end{array}$ & $\begin{array}{l}\text { Ruta 200c; Carcinosinum } \\
\text { 200c; Thuja 200c }\end{array}$ & $\begin{array}{l}\text { Dalton's lymphoma } \\
\text { ascites (DLA) cells }\end{array}$ & Increased apoptosis in DLA cells \\
\hline Frenkel et al $2010^{44}$ & $\begin{array}{l}\text { Carcinosinum 30c; } \\
\text { Phytolacca 200c; Conium 3c; } \\
\text { Thuja 30c }\end{array}$ & $\begin{array}{l}\text { Human MCF-7 and } \\
\text { MDA-MB-231 breast } \\
\text { adenocarcinoma cells }\end{array}$ & $\begin{array}{l}\text { Increased apoptosis in breast } \\
\text { adenocarcinoma cells }\end{array}$ \\
\hline Samadder et al $2013^{45}$ & Lycopodium 5c, 15c & HeLa cells & Increased apoptosis in HeLa cells \\
\hline Arora et al $2013^{46}$ & $\begin{array}{l}\text { Sarsaparilla, Ruta, Phytolacca } \\
\text { (MT, 30c, 200c, 1M, 10M) }\end{array}$ & $\begin{array}{l}\text { Human renal } \\
\text { adenocarcinoma, } \\
\text { colorectal carcinoma and } \\
\text { breast carcinoma cells }\end{array}$ & $\begin{array}{l}\text { MT and potentized drugs } \\
\text { produced apoptosis in the } \\
\text { respective cancer cell lines }\end{array}$ \\
\hline Bishayee et al $2013^{47}$ & Condurango $30 \mathrm{c}$ & HeLa cells & Increased apoptosis in HeLa cells \\
\hline Sikdar et al $2014^{48}$ & Condurango $6 \mathrm{c}, 30 \mathrm{c}$ & $\begin{array}{l}\text { H460-non-small-cell lung } \\
\text { cancer (NSCLC) cells }\end{array}$ & Induced apoptosis in NSCLC cells \\
\hline Arora and Tandon $2015^{49}$ & Ruta MT, 30c & $\begin{array}{l}\text { COLO-205 colon } \\
\text { carcinoma cells }\end{array}$ & $\begin{array}{l}\text { Induced apoptosis in COLO-205 } \\
\text { cells }\end{array}$ \\
\hline Saha et al $2015^{50}$ & Sulfur 6c, 30c, 200c & $\begin{array}{l}\text { Non-small cell lung } \\
\text { carcinoma (NSCLC) cells }\end{array}$ & Induced apoptosis in NSCLC cells \\
\hline Mondal et al $2016^{51}$ & Psorinum 6c & A549 lung cancer cells & $\begin{array}{l}\text { Triggered apoptosis in A549 lung } \\
\text { cancer cells }\end{array}$ \\
\hline
\end{tabular}

Abbreviation: MT, mother tincture.

isopathy (from the Greek prefixes, isos, 'same' and pathos, 'disease') would only be justified if it were possible to redirect it to the fundamental cause of diseases.

As Hahnemann himself highlights in relation to isopathy: ${ }^{3}$ 'A third mode of employing medicines in diseases has been attempted to be created by means of isopathy, as it is called: that is to say, a method of curing a given disease by the same contagious principle that produces it. But even granting this could be done, yet, after all, seeing that the miasm is given to the patient highly potentized, and consequently, in an altered condition, the cure is effected only by opposing a simillimum to a simillimum' (Organon, note on paragraph 56)..$^{3}$

By regarding disease-promoting epigenetic alterations as simillimum or biological representation of the chronic miasms (fundamental cause of chronic diseases, according to both rationales), the isopathic use of auto-sarcode of DNA could be employed as anti-miasmatic homeopathic medicine and modulator of gene expression, by acting as general or specific reactional or isopathic medicine according to the therapeutic approach proposed and the genetic material selected for the preparation.

If we use generic DNA extracted from whole blood or any biological sample (auto-sarcode of general DNA), we would be acting on the epigenome systemic modulation, seeking to restore the organism's dynamic, complex, and global balance, either associated or not with chronic diseases. In turn, as long as it is feasible, by employing DNA extracted from specific tissues (auto-sarcode of specific DNA), we would be enhancing the response by directing gene modulation 
Table 3 Experiments with potentized homeopathic medicines causing therapeutic change in gene expression

\begin{tabular}{|c|c|c|c|}
\hline Author(s), date & $\begin{array}{l}\text { Potentized } \\
\text { drugs }\end{array}$ & Model of study & Effects \\
\hline $\begin{array}{l}\text { Khuda-Bukhsh } \\
\text { et al } 2011^{52}\end{array}$ & Secale 30c & $\begin{array}{l}\text { Croton oil-induced skin } \\
\text { papilloma in mice }\end{array}$ & $\begin{array}{l}\text { Decreased DNA damage (modulated gene } \\
\text { expression levels) with amelioration of skin } \\
\text { papilloma }\end{array}$ \\
\hline Das et al $2011^{53}$ & Arsenicum 30c & $\begin{array}{l}\text { Saccharomyces cerevisiae } \\
\text { exposed to arsenate }\end{array}$ & $\begin{array}{l}\text { Decreased DNA damage (down-regulated expres- } \\
\text { sion of Msn } 2 \text { and Yca-1 genes) and increased cell } \\
\text { viability }\end{array}$ \\
\hline De et al $2012^{54}$ & Arsenicum 30c & $\begin{array}{l}\text { Escherichia coli exposed to } \\
\text { arsenite }\end{array}$ & $\begin{array}{l}\text { Decreased DNA damage (up-regulated expression } \\
\text { of arsenic-resistant genes) and increased cell } \\
\text { viability }\end{array}$ \\
\hline Das et al $2012^{55}$ & Arnica 30c & $\begin{array}{l}\text { Escherichia coli exposed to } \\
\text { ultraviolet irradiation }\end{array}$ & $\begin{array}{l}\text { Decreased DNA damage (up-regulated nucleotide } \\
\text { excision repair genes) and increased cell viability }\end{array}$ \\
\hline Bishayee et al $2013^{47}$ & Condurango 30c & HeLa cells & $\begin{array}{l}\text { Reduced histone de-acetylase (HDAC2) activity, } \\
\text { epigenetic event of gene modulation in combating } \\
\text { cancer cells }\end{array}$ \\
\hline Marotti et al $2014^{56}$ & Arsenicum 45x & $\begin{array}{l}\text { Wheat seedlings } \\
\text { poisoned with sub-lethal } \\
\text { dose of arsenic }\end{array}$ & $\begin{array}{l}\text { Down-regulated expression of genes that were up- } \\
\text { regulated during the oxidative stress }\end{array}$ \\
\hline Bigagli et al $2014^{37}$ & $\begin{array}{l}\text { Apis mellifica MT, } \\
3 c, 5 c, 7 c\end{array}$ & $\begin{array}{l}\text { Human RWPE-1 prostate } \\
\text { epithelial cell line }\end{array}$ & $\begin{array}{l}\text { Apis } \mathrm{MT}, 3 c, 5 c, 7 c \text { caused significant changes on } \\
\text { genes involved in inflammation and oxidative } \\
\text { stress }\end{array}$ \\
\hline $\begin{array}{l}\text { Marzotto et al } 2014^{38} \\
\text { Olioso et al } 2014^{39} \\
\text { Marzotto et al } 2014^{40} \\
\text { Bellavite et al } 2018^{41}\end{array}$ & Gelsemium 2c & $\begin{array}{l}\text { Human SHSY5Y neuro- } \\
\text { cytes cell line }\end{array}$ & $\begin{array}{l}\text { Down-regulated of gene involved in nociception } \\
\text { and in depression-like behavior, causing anxiolytic } \\
\text { and analgesic effects }\end{array}$ \\
\hline $\begin{array}{l}\text { Khuda-Bukhsh } \\
\text { and Sikdar } 2015^{57}\end{array}$ & Condurango $30 \mathrm{c}$ & $\begin{array}{l}\text { H460-NSCLC cell and BaP- } \\
\text { induced lung cancer of } \\
\text { rats }\end{array}$ & $\begin{array}{l}\text { Significant decrease in band intensity of p15 and } \\
\text { p53 genes; epigenetic event involved in DNA } \\
\text { hyper-methylation }\end{array}$ \\
\hline Saha et al $2015^{58}$ & $\begin{array}{l}\text { Hydrastis 30c, } \\
\text { Condurango 30c }\end{array}$ & HeLa cells & $\begin{array}{l}\text { Altered methylation in specific regions of DNA } \\
\text { (epigenetic event) and expression profiles of many } \\
\text { genes associated with carcinogenesis }\end{array}$ \\
\hline $\begin{array}{l}\text { Olioso et al } 2016^{59} \\
\text { Olioso et al } 2016^{60}\end{array}$ & Arnica 1c & $\begin{array}{l}\text { THP-1 human macro- } \\
\text { phage cell line }\end{array}$ & $\begin{array}{l}\text { Modified the expression of genes that are key } \\
\text { regulators of tissue re-modelling, inflammation } \\
\text { and chemotaxis }\end{array}$ \\
\hline Olsen $2017^{61}$ & $\begin{array}{l}\text { Butyric acidum } \\
30 c, 200 c\end{array}$ & $\begin{array}{l}\text { Human embryonic kidney } \\
\text { (HEK) } 293 \text { cells }\end{array}$ & Modulated the gene expression of HEK 293 cells \\
\hline
\end{tabular}

Abbreviation: MT, mother tincture.

toward epigenetic modifications that are located in particular tissues, which are responsible for manifesting and maintaining specific chronic diseases.

Reiterating the possible therapeutic recommendations related to the homeopathic chronic miasms and their epigenetic representations, while the auto-sarcode of general DNA would act as anti-psoric medicine on the general epigenome modulation, the auto-sarcode of specific DNA would act as specific anti-miasmatic medicine by amplifying the epigenome modulation to the epigenetic alterations located in particular tissues.

By way of clarification of the varied terminology, in many countries the term 'isotherapy' is used as alternative nomenclature to 'isopathy', as well as 'isotherapic' medicine as an alternative to 'isopathic' medicine. According to the Brazilian Homeopathic Pharmacopoeia, 27 in the chapter 'Biotherapics and Isotherapics', 'isotherapics' are described as 'medicinal preparations obtained from inputs related to the patient's pathology that are prepared following the homeopathic, pharmaco-technical method and are classified as auto-isotherapics and hetero-isotherapics'. 'Autoisotherapics' are 'isotherapics whose active inputs are obtained from the very patient (fragments of organs and tissues, blood, secretions, excretions, calculus, feces, urine and microbial cultures, among others) and are destined to this specific patient'. Following the 'Minimum Requirements for the Preparation of Biotherapics and Isotherapics', complying with the biosafety norms of the Brazilian health surveillance, ${ }^{28}$ 'auto-isotherapics can only be stored in alcohol at $70 \%(\mathrm{v} / \mathrm{v})$ and dispensed from $12 \mathrm{cH}$ or $24 \mathrm{dH},{ }^{27}$ concentrations that are below the Avogadro limit $\left(6.023 \times 10^{-23}\right)$.

Extraction and purification procedures of genetic material (general or specific DNA) from patients must be performed 
Table 4 Protocol for the preparation of auto-sarcode of DNA

\begin{tabular}{|c|c|}
\hline $\begin{array}{l}\text { 1. Receiving the material from the molecular biology } \\
\text { laboratory (DNA soluble in tris-EDTA) }\end{array}$ & 6. Apply 100 strong succussions, obtaining the $1 \mathrm{cH}$ potency \\
\hline $\begin{array}{l}\text { 2. Add alcohol } 96^{\circ} \mathrm{GL} \text { to the material. The filament of } \\
\text { DNA will precipitate }\end{array}$ & $\begin{array}{l}\text { 7. Transfer } 1 \text { drop of } 1 \mathrm{cH} \text { potency to another vial containing } \\
99 \text { drops of distilled water and apply } 100 \text { strong succussions } \\
\text { to obtain } 2 \mathrm{cH} \text { potency }\end{array}$ \\
\hline $\begin{array}{l}\text { 3. Wash the filament of DNA with alcohol } 96^{\circ} \mathrm{GL} \text { to } \\
\text { remove residue of tris-EDTA adsorbed }\end{array}$ & $\begin{array}{l}\text { 8. Repeat the previous procedure to obtain } 3 \mathrm{cH} \text { to } 11 \mathrm{cH} \\
\text { potencies }\end{array}$ \\
\hline $\begin{array}{l}\text { 4. Transfer the DNA filament with } 1 \text { drop of alcohol } 96^{\circ} \\
G L \text { to vial for dynamization (potentization) }\end{array}$ & $\begin{array}{l}\text { 9. In the preparation of } 12 \mathrm{cH} \text { potency, make alcohol dilution } \\
77 \%(\mathrm{v} / \mathrm{v}) 1: 99 \text { ratio and apply } 100 \text { succussions }\end{array}$ \\
\hline $\begin{array}{l}\text { 5. Add } 99 \text { drops of distilled water to the vial. The DNA } \\
\text { will become soluble again }\end{array}$ & 10. Repeat the process until the desired potency is obtained \\
\hline
\end{tabular}

Abbreviation: EDTA, ethylenediaminetetraacetic acid; GL, Gay-Lussac.

by molecular biology laboratories following specific techniques and protocols ${ }^{29,30}$ and later forwarded to pharmacies or homeopathic laboratories, so as to have auto-sarcode prepared following the homeopathic, pharmaco-technical method. ${ }^{27}$ As an example of whole-blood general DNA extraction, the process is automated and uses specific methods and kits, ${ }^{31}$ and the material is delivered in buffer solution (DNA dissolved in tris-EDTA), with concentration and purity informed.

Since the DNA extracted is soluble in distilled water and non-soluble in alcohol (it precipitates and preserves its integrity), these means must be used in distinct phases of the material's dynamization (potentization) process. In view of these peculiar DNA properties and pharmaco-technical requirements, it is suggested that a 'Protocol for the preparation of auto-sarcode of DNA' be followed (-Table 4).

\section{Conclusions}

By modulating the constitutional epigenomic expression and performing possible prophylactic and therapeutic global actions that are not necessarily associated with specific tissues or diseases (e.g. increasing cellular resistance, stimulating repair or regeneration systems, restoring the specific characteristics of certain body systems), I believe that the isopathic use of auto-sarcode of general DNA can systematically act favorably on chronic disorders and diseases in general. In turn, the auto-sarcode of specific DNA would act on directing gene modulation toward the epigenetic alterations that are located in specific tissues and are responsible for certain chronic diseases.

In applying this proposition, it is assumed that autosarcode at different potencies should be applied gradually so that the desired therapeutic response is achieved. Furthermore, by acting on the dynamic modulation of gene expression, I believe that periodic DNA extractions are needed, as well as the resulting auto-sarcode preparations and prescriptions, so that the modulation process occurs progressively over the years.

Reiterating that this is a theoretical hypothesis with no scientific evidence at this moment, it must be stressed that the general use in humans can only be extended if studies were conducted that prove its efficacy and safety. Thus, the disclosure of this embryonic and innovative proposition aims at bringing researchers together around it, by encouraging them to conduct basic research and clinical trials to either confirm or refute its validity. Since it is a therapeutic procedure in humans with 'manipulation' of genetic material, following national and international legislations ${ }^{32,33}$ we must prioritize the bioethical principle of non-maleficence before that of beneficence.

Concerning this issue, it is worth pointing out that the long-standing therapeutic use of homeopathic high dilutions (at concentration values that are below the Avogadro limit) of several toxic agents has made the safety of homeopathic methods clear. ${ }^{34,35}$ Furthermore, it is worth pointing out that the safety warnings regarding classic gene therapy (genetic engineering) refer to injecting exogenous genes (DNA vaccines) into the body or applying recombinant DNA technologies that allow modifications to be made to the genome per $s e$ (introduction of 'therapeutic' genes in cells with the use of vectors): ${ }^{12,16}$ such processes are not present in the referred proposal of production and application of auto-sarcode of DNA (- Table 4).

Since it is a proposition that is easily applied and adjusted to any existing experimental or clinical research model for a wide range of disorders and diseases, I believe that studies that validate the method's efficacy and safety can be quickly conducted. In this context, several variables should be tested: most recommended dosages and potencies for each type of approach and individual (individualization of doses and potencies); treatment time needed so that laboratory and clinical responses may be observed; use of approaches proposed either individually or jointly (auto-sarcode of general and/or specific DNA) for each type of disorder or disease; ideal time intervals for performing periodic extractions and resulting preparation and prescription of autosarcode of DNA; and concomitant use of classical homeopathic medicines.

Should the proposed hypothesis be confirmed in practice, we would be able to employ a new homeopathic therapeutic approach to alleviate the human suffering resulting from countless chronic diseases and expand the homeopathic treatment spectrum. 


\section{Highlights}

- Vitalism and miasmatic theory are used to broaden the understanding of the health-disease process.

- The chronic miasms are the main obstacle to the homeopathic healing of chronic diseases.

- Disease-promoting epigenetic modifications are the biological representation of the chronic miasms.

- Anti-miasmatic homeopathic medicines are used to cure the miasms and their consequent chronic diseases.

- Isopathic use of auto-sarcode of DNA can be employed as anti-miasmatic homeopathic medicine and gene expression modulator.

\section{Funding \\ None.}

\section{Conflict of Interest}

None declared.

\section{References}

1 Teixeira MZ. Proofs that homeopathic medicine works: dossier "scientific evidence for homeopathy" (Revista de Homeopatia, São Paulo Homeopathic Medical Association). Homeopathy 2018;107:45

2 Teixeira MZ. Special dossier: "Scientific Evidence for Homeopathy". Rev Assoc Med Bras (1992) 2018;64:93-94

3 Hahnemann S. Organon der Heilkunst. Organon da arte de curar. 6th ed. Ribeirão Preto: Museu de Homeopatia Abrahão Brickmann; 1995

4 Teixeira MZ. A concepção vitalista de Samuel Hahnemann [The vitalist conception of Samuel Hahnemann]. Rev Homeopatia (São Paulo) 1996;61:39-44

5 Teixeira MZ. Antropologia Médica Vitalista: uma ampliação ao entendimento do processo de adoecimento humano [Vitalist Medical Anthropology: a broadening to the understanding of the human illness process]. Rev Med (São Paulo) 2017;96:145-158

6 Hahnemann S. The Chronic Diseases, their peculiar nature and their homeopathic cure. Translated from the second enlarged German edition of 1835 by Prof. Louis H. Tafel. With annotations by Richard Hughes. Edited by Pemberton Dudley. Available at: http://homeoint.org/books/hahchrdi/index.htm. Accessed September 20, 2018

7 Venter JC, Adams MD, Myers EW, et al. The sequence of the human genome. Science 2001;291:1304-1351

8 Holliday R. Epigenetics: a historical overview. Epigenetics 2006; $1: 76-80$

9 Kouzarides T. Chromatin modifications and their function. Cell 2007;128:693-705

10 García R, Ayala PA, Perdomo SP. Epigenética: definición, bases moleculares e implicaciones en la salud y en la evolución humana [Epigenetics: definition, molecular bases and implications in human health and evolution]. Rev Cienc Salud 2012;10:59-71

11 Feinberg AP, Tycko B. The history of cancer epigenetics. Nat Rev Cancer 2004;4:143-153

12 Costa EBO, Pacheco C. Epigenética: regulação da expressão gênica em nível transcricional e suas implicações [Epigenetics: gene expression regulation at transcriptional level and its implications]. Semina: Ciências Biológicas e da Saúde (Londrina) 2013;34:125-136

13 Schultz MD, He Y, Whitaker JW, et al. Human body epigenome maps reveal noncanonical DNA methylation variation. Nature 2015;523:212-216

14 Jirtle RL, Skinner MK. Environmental epigenomics and disease susceptibility. Nat Rev Genet 2007;8:253-262

15 Dolinoy DC, Jirtle RL. Environmental epigenomics in human health and disease. Environ Mol Mutagen 2008;49:4-8
16 Linden R. Terapia gênica: o que é, o que não é e o que será [Gene therapy: what it is, what it is not and what it will be]. Estud Av 2010;24:31-69

17 Crews D, Gillette R, Scarpino SV, Manikkam M, Savenkova MI, Skinner MK. Epigenetic transgenerational inheritance of altered stress responses. Proc Natl Acad Sci U S A 2012; 109:9143-9148

18 Babenko O, Kovalchuk I, Metz GA. Stress-induced perinatal and transgenerational epigenetic programming of brain development and mental health. Neurosci Biobehav Rev 2015;48:70-91

19 Bellavite P, Pettigrew A. Miasms and modern pathology. Homeopathy 2004;93:65-66

20 Gulati R. The concept of miasm. Homeopathy 2010;99:150

21 Khuda-Bukhsh AR. Potentized homoeopathic drugs act through regulation of gene-expression: a hypothesis to explain their mechanism and pathways of action in vitro. Complement Ther Med 1997;5:43-46

22 Khuda-Bukhsh AR. Towards understanding molecular mechanisms of action of homeopathic drugs: an overview. Mol Cell Biochem 2003;253:339-345

23 Khuda-Bukhsh AR. Current trends in high dilution research with particular reference to gene regulatory hypothesis. Nucleus 2014; 57:3-17

24 Kay PH, Khuda-Bukhsh AR. The contribution of homeogenomic and homeogenetic studies in the support of the practice of homoeopathy. Indian J Res Homoeopathy 2016;10:101-107

25 Dei A, Bernardini S. Hormetic effects of extremely diluted solutions on gene expression. Homeopathy 2015;104:116-122

26 Bellavite P, Signorini A, Marzotto M, Moratti E, Bonafini C, Olioso D. Cell sensitivity, non-linearity and inverse effects. Homeopathy 2015;104:139-160

27 Agência Nacional de Vigilância Sanitária (ANVISA) [The National Health Surveillance Agency]. Farmacopeia Homeopática Brasileira [Brazilian Homeopathic Pharmacopoeia]. 3rd ed. Brasília: ANVISA, 2011. Available at: http://portal.anvisa.gov.br/farmacopeia-homeopatica. Accessed September 20, 2018

28 Agência Nacional de Vigilância Sanitária (ANVISA) [The National Health Surveillance Agency]. Resolução da Diretoria Colegiada RDC $n^{\circ}$ 67, de 08 de outubro de 2007. Diário Oficial da República Federativa do Brasil, Poder Executivo, Brasília, DF, 09 out. 2007. Available at: http://189.28.128.100/dab/docs/legislacao/resolucao67_08_10_07.pdf. Accessed September 20, 2018

29 Tan SC, Yiap BC. DNA, RNA, and protein extraction: the past and the present. J Biomed Biotechnol 2009;2009:574398

30 El-Ashram S, Al Nasr I, Suo X. Nucleic acid protocols: extraction and optimization. Biotechnol Rep (Amst) 2016;12:33-39

31 Qiagen. QIAsymphony ${ }^{\circledR}$ DSP DNA Instructions for Use (Handbook), 2015. Available at: https://www.qiagen.com/us/resources/download.aspx?id=8bc88dad-4140-467e-a1f0-e390fd193865\&lang=en . Accessed September 20, 2018

32 Conselho Nacional de Saúde (Brasil). Resolução CNS N ${ }^{\circ} 340$, de 8 de julho de 2004. Diretrizes para Análise Ética e Tramitação dos Projetos de Pesquisa da Área Temática Especial de Genética Humana. Available at: http://bvsms.saude.gov.br/bvs/saudelegis/cns/2004/ res0340_08_07_2004.html. Accessed September 20, 2018

33 Gene Therapy Net. Gene Therapy Clinical Trials Regulatory Affairs. Available at: http://www.genetherapynet.com/regulatory-affairs. html. Accessed September 20, 2018

34 Dantas F, Rampes H. Do homeopathic medicines provoke adverse effects? A systematic review. Br Homeopath J 2000;89:S35-S38

35 Dantas F. Do homeopathic medicines cause drug-dependent adverse effects or aggravations? Rev Homeopatia (São Paulo) 2017;80:142-150

36 Khuda-Buksh AR, Saha SK, Roy S. Evidence in support of gene regulatory hypothesis: gene expression profiling manifests homeopathy effects more than placebo. Int J High Dilution Res 2013;12:162-167 
37 Bigagli E, Luceri C, Bernardini S, Dei A, Filippini A, Dolara P. Exploring the effects of homeopathic Apis mellifica preparations on human gene expression profiles. Homeopathy 2014;103:127-132

38 Marzotto M, Olioso D, Brizzi M, Tononi P, Cristofoletti M, Bellavite P. Extreme sensitivity of gene expression in human SH-SY5Y neurocytes to ultra-low doses of Gelsemium sempervirens. BMC Complement Altern Med 2014;14:104

39 Olioso D, Marzotto M, Moratti E, Brizzi M, Bellavite P. Effects of Gelsemium sempervirens L. on pathway-focused gene expression profiling in neuronal cells. J Ethnopharmacol 2014;153:535-539

40 Marzotto M, Olioso D, Bellavite P. Gene expression and highly diluted molecules. Front Pharmacol 2014;5:237

41 Bellavite P, Bonafini C, Marzotto M. Experimental neuropharmacology of Gelsemium sempervirens: recent advances and debated issues. J Ayurveda Integr Med 2018;9:69-74

42 Sunila ES, Kuttan R, Preethi KC, Kuttan G. Dynamized preparations in cell culture. Evid Based Complement Alternat Med 2009; 6:257-263

43 Preethi K, Ellanghiyil S, Kuttan G, Kuttan R. Induction of apoptosis of tumor cells by some potentiated homeopathic drugs: implications on mechanism of action. Integr Cancer Ther 2012; $11: 172-182$

44 Frenkel M, Mishra BM, Sen S, et al. Cytotoxic effects of ultra-diluted remedies on breast cancer cells. Int J Oncol 2010;36:395-403

45 Samadder A, Das S, Das J, Paul A, Boujedaini N, Khuda-Bukhsh AR. The potentized homeopathic drug, Lycopodium clavatum (5C and 15C) has anti-cancer effect on HeLa cells in vitro. J Acupunct Meridian Stud 2013;6:180-187

46 Arora S, Aggarwal A, Singla P, Jyoti S, Tandon S. Anti-proliferative effects of homeopathic medicines on human kidney, colon and breast cancer cells. Homeopathy 2013;102:274-282

47 Bishayee K, Sikdar S, Khuda-Bukhsh AR. Evidence of an epigenetic modification in cell-cycle arrest caused by the use of ultra-highlydiluted Gonolobus condurango extract. J Pharmacopuncture 2013;16:7-13

48 Sikdar S, Kumar Saha S, Rahman Khuda-Bukhsh A. Relative apoptosis-inducing potential of homeopathic Condurango $6 \mathrm{c}$ and 30c in h460 lung cancer cells in vitro: apoptosis-induction by homeopathic Condurango in h460 cells. J Pharmacopuncture 2014;17:59-69

49 Arora S, Tandon S. DNA fragmentation and cell cycle arrest: a hallmark of apoptosis induced by Ruta graveolens in human colon cancer cells. Homeopathy 2015;104:36-47

50 Saha S, Bhattacharjee P, Guha D, et al. Sulphur alters NFkB-p300 cross-talk in favour of p53-p300 to induce apoptosis in non-small cell lung carcinoma. Int J Oncol 2015;47:573-582
51 Mondal J, Samadder A, Khuda-Bukhsh AR. Psorinum $6 \times$ triggers apoptosis signals in human lung cancer cells. J Integr Med 2016; 14:143-153

52 Khuda-Bukhsh AR, Bhattacharyya SS, Paul S, Dutta S, Boujedaini $\mathrm{N}$, Belon P. Modulation of signal proteins: a plausible mechanism to explain how a potentized drug Secale cor 30c diluted beyond Avogadro's limit combats skin papilloma in mice. Evid Based Complement Alternat Med 2011;2011:286320

53 Das D, De A, Dutta S, Biswas R, Boujedaini N, Khuda-Bukhsh AR. Potentized homeopathic drug Arsenicum Album 30C positively modulates protein biomarkers and gene expressions in Saccharomyces cerevisiae exposed to arsenate. J Chin Integr Med 2011; 9:752-760

54 De A, Das D, Dutta S, Chakraborty D, Boujedaini N, KhudaBukhsh AR. Potentiated homeopathic drug Arsenicum Album $30 \mathrm{C}$ inhibits intracellular reactive oxygen species generation and up-regulates expression of arsenic resistance gene in arseniteexposed bacteria Escherichia coli. J Chin Integr Med 2012; 10:210-227

55 Das S, Saha SK, De A, Das D, Khuda-Bukhsh AR. Potential of the homeopathic remedy, Arnica Montana 30C, to reduce DNA damage in Escherichia coli exposed to ultraviolet irradiation through upregulation of nucleotide excision repair genes. J Chin Integr Med 2012;10:337-346

56 Marotti I, Betti L, Bregola V, et al. Transcriptome profiling of wheat seedling following treatment with ultrahigh diluted arsenic trioxide. Evid Based Complement Alternat Med 2014; 2014:851263

57 Khuda-Bukhsh AR, Sikdar S. Condurango 30c induces epigenetic modification of lung cancer-specific tumour suppressor genes via demethylation. Forsch Komplement Med 2015;22:172-179

58 Saha SK, Roy S, Khuda-Bukhsh AR. Ultra-highly diluted plant extracts of Hydrastis canadensis and Marsdenia condurango induce epigenetic modifications and alter gene expression profiles in HeLa cells in vitro. J Integr Med 2015;13:400-411

59 Olioso D, Marzotto M, Bonafini C, Brizzi M, Bellavite P. Arnica Montana effects on gene expression in a human macrophage cell line. Evaluation by quantitative real-time PCR. Homeopathy 2016; 105:131-147

60 Olioso D, Marzotto M, Bonafini C, Brizzi M, Bellavite P. Response to commentary: Arnica montana effects on gene expression in a human macrophage cell line. Evaluation by quantitative real-time PCR. Front Immunol 2016;7:320

61 Olsen S. Effects of ultra-high dilutions of sodium butyrate on viability and gene expression in HEK 293 cells. Homeopathy 2017; 106:32-36 